\section{Rootstock and Training System Affect Sweet Cherry Growth, Yield, and Fruit Quality}

\author{
Matthew D. Whiting, ${ }^{1}$ Gregory Lang, and David Ophardt \\ Washington State University, Irrigated Agriculture Research and Extension \\ Center, 24106 North Bunn Road, Prosser, WA 99350
}

Additional index words. Prunus avium, canopy architecture, fruit size, yield efficiency, crop value

\begin{abstract}
Traditional sweet cherry (Prunus avium L.) training systems in the United States are based upon vigorous rootstocks and multiple leader vase canopy architectures. The sweet cherry research lab at Washington State University has been investigating the potential of new rootstocks and training systems to improve production efficiency and produce high quality fruit. This paper describes the effects of three rootstocks-Mazzard (P. avium), 'Gisela 6', and 'Gisela 5' (P. cerasus $\times$ P. canescens $)$ - and four training systems - central leader, multiple-leader bush, palmette, and y-trellis — on 'Bing' sweet cherry tree vigor, fruit yield and quality over a seven year period. Compared to trees on Mazzard, trees on 'Gisela 5' and 'Gisela 6' had 45\% and $20 \%$ lower trunk cross-sectional areas after 7 seasons, respectively. Trees on 'Gisela 6' were the most productive, yielding between $13 \%$ and $31 \%$ more than those on 'Gisela 5 ' and $657 \%$ to $212 \%$ more than trees on Mazzard, depending on year. Both Gisela rootstocks significantly improved precocity compared to Mazzard, bearing fruit in year 3 in the orchard. Canopy architecture had only moderate effects on tree vigor and fruit yield. Across rootstocks, bush-trained trees were about $25 \%$ less productive compared to the other systems, which exhibited similar cumulative yields $(102 \mathrm{~kg} /$ tree $)$. Fruit weight was negatively and closely $\left(r^{2}=0.84\right)$ related to tree yield efficiency $\left(\mathrm{kg} \cdot \mathrm{cm}^{-2}\right)$. Crop value was related positively to fruit yield.
\end{abstract}

Traditionally, in the Pacific northwestern U.S., sweet cherry (Prunus avium L.) trees have been trained to a multiple leader, open center architecture, grown on vigorous seedling rootstocks (e.g., Mazzard (P. avium L.) and Mahaleb (P. mahaleb L.)), and planted at tree densities of 250 to 400 trees per ha. When mature, these production systems may be high-yielding and bear excellent quality fruit. However, these systems lack precocity, typically bearing the first crop 4 to 6 years after planting and not achieving full production until 8 to 12 years after planting. This is undesirable due to the delayed return on the investment from establishing the orchard. Therefore, sweet cherry growers have attempted to induce early fruiting using various techniques (e.g., deficitirrigation, limb bending, applications of ethephon, etc.).

At maturity, the traditional systems are comprised of trees that are tall, spreading and inherently inefficient to harvest and prune, requiring significant use of ladders. Moreover, labor is expensive in Washington State and becoming scarce, particularly for harvest, as sweet cherry acreage has nearly doubled over the past 10 years. To improve sweet cherry production efficiency, research is needed to develop novel production systems that hasten fruit production and improve labor efficiency and safety. These

Received for publication 6 Aug. 2004. Accepted for publication 18 Oct. 2004. We are grateful to Amanda Christopher and Tammy Killian for their technical assistance and to the International Dwarf Fruit Tree Association and the Washington Tree Fruit Research Commission for financial support.

${ }^{1}$ Author to whom reprint requests should be addressed; e-mail mdwhiting@wsu.edu. objectives have been accomplished in other tree fruit species genetically (e.g., size-controlling and precocious rootstocks) and horticulturally (e.g., training systems). To date there has been very little research on the effects of rootstock and/or training system on vigor, precocity, and fruit quality of sweet cherry.

The effects of rootstock genotype on fruit yield and quality and tree vigor have been well documented in many tree species, especially apple (Malus $\times$ domestica Borkh.) (Autio and Southwick, 1986; Fallahi et al., 2002; Marini et al., 2002; Schecter et al., 1991; ), but also for peach (P. persica L.) (Kappel and Bouthillier, 1995; Layne, 1994) and citrus (Roose et al., 1989; Wheaton et al., 1991). New rootstocks for sweet cherry have recently been developed and adopted commercially (Lang, 2000; Perry et al., 1997), albeit on a limited basis in North America. Of the next generation of sweet cherry rootstocks, the most widely-adopted selections are from the 'Gisela' series (Webster and Schmidt, 1996) developed in Germany. In the Pacific Northwest, about one-third of newly planted orchards are rooted on 'Gisela 5 ' or 'Gisela 6' (P. cerasus $\times$ P. canescens $)$. In general, these rootstocks improve precocity and reduce scion vigor, with 'Gisela 5' being more dwarfing than 'Gisela 6' (Perry et al., 1997). Whiting and Lang (2004) showed that 'Bing' on 'Gisela 5' has a propensity to set a heavy crop and will require novel crop load management strategies to balance fruit number with canopy area. However, very little is published on the long term effect these rootstocks have on scion precocity, productivity, and vigor in managed production systems.
Canopy architecture also affects tree productivity, production efficiency, and fruit quality in apple (Hampson et al., 2002; Robinson et al., 1991; Miller, 1984). Such information for sweet cherry, especially comparing the effects of new clonal rootstocks, is not yet available. In apple, training system impacts tree growth, light interception, light distribution, fruit yield, distribution, and quality, and net photosynthesis and transpiration (Ferree et al., 1993; Hampson et al., 2002; Jackson, 1980; Robinson, 1997; Robinson et al., 1991). Irrespective of rootstock, new sweet cherry orchards are being planted at higher than traditional tree densities because growers wish to improve economic returns and labor efficiency. Moreover, sweet cherry orchards are being trained to systems other than the traditional multiple-leader, open center vase architecture to improve tree precocity, more precisely manage canopy growth and fruiting, and improve labor efficiency by reducing canopy volume and lowering the fruiting zone to a height where a high percentage of fruit may be harvested without ladders. To date very little research has examined the influence of canopy architecture on sweet cherry tree growth, yield, and fruit quality. Across four cultivars, Moreno et al. (1998) found higher sweet cherry yield efficiency but lower fruit quality with palmette and marchand training systems compared to the multiple leader vase.

The objective of this research was to compare the effects of sweet cherry canopy architecture and rootstock on tree vigor, fruit yield, and fruit quality.

\section{Materials and Methods}

Commercially produced 'Bing' sweet cherry trees on Mazzard, 'Gisela 5', and 'Gisela 6' rootstocks were planted in spring, 1995 at Washington State University's Roza experimental farm (lat. $46.2^{\circ} \mathrm{N}$, long. $119.7^{\circ} \mathrm{W}$ ) in north to south rows at $2.6 \times 4.9 \mathrm{~m}$ (about 864 trees/ha). The orchard site is a silty loam limited by basalt at a depth of about $1 \mathrm{~m}$. The experimental orchard was watered weekly from mid-April to late October by undertree microsprinklers arranged in a diamond pattern (i.e., every second tree). Standard pest management and nutrition practices were followed. Ground broadcast application of nitrogen fertilizer was withheld during 2001-03 seasons because of excessive vigor.

Trees were trained to a trellised palmette (P), central leader (CL), y-trellis (Y), or bush (B) system beginning in spring, 1995. Entire rows were trained to a similar system and training system was replicated three times randomly throughout the orchard. Within each row, rootstocks were replicated three times randomly in groups of three trees. The middle trees were used for data collection. At maturity, the $\mathrm{P}$ system was characterized by multiple permanent scaffolds (4 to 5) in a single plane along the row with lateral fruiting limbs arising from the scaffolds into the alleyway. The CL trees had two to three whorls of fruiting scaffolds, arising about every $1 \mathrm{~m}$, from the central leader. The $\mathrm{Y}$ trees were comprised of 
Table 1. Value per size category used in economic analyses.

\begin{tabular}{lcc}
\hline $\begin{array}{l}\text { Fruit } \\
\text { size } \\
(\mathrm{mm})\end{array}$ & $\begin{array}{l}\text { Row } \\
\text { size }\end{array}$ & $\begin{array}{l}\text { Value } \\
(\$ / \mathrm{kg})\end{array}$ \\
\hline$\geq 30$ & $\geq 9$ & 3.69 \\
28.2 & 9.5 & 3.47 \\
26.6 & 10 & 3.20 \\
25.4 & 10.5 & 2.58 \\
24.2 & 11 & 2.24 \\
22.6 & 11.5 & 1.86 \\
21.4 & 12 & 1.46 \\
20.6 & 13 & 0.54 \\
19.0 & 14 & 0.00 \\
\hline
\end{tabular}

two main scaffolds per tree (one per trellis) at $60^{\circ}$ between them with subscaffolds and fruiting laterals arising from them and trained to the trellis. The B trees were trained following the standard Spanish Bush protocol (Long, 2001). Briefly, trees were headed after planting at about $40 \mathrm{~cm}$ above the ground and primary branches were headed again after about 50 $\mathrm{cm}$ of growth. In the second season, branches were twice headed again, once before bud break and then after about $50 \mathrm{~cm}$ of growth. In subsequent seasons, trees were only dormant pruned for light penetration and renewal of fruiting wood. At maturity and irrespective of training system and rootstock, tree height was maintained at $\leq 5 \mathrm{~m}$. With the exception of B trees that were summer pruned in the first 3 years, trees received only dormant pruning for light distribution and canopy architecture.

Every year, optimum harvest was determined as the point at which most fruit exhibited mahogany skin color. All fruit were hand-harvested within a two day period by commercial picking crews. At harvest, tree yield was recorded in the field and subsamples (minimum of 100 fruit) were selected randomly and analyzed in the lab for fruit quality as described in Whiting and Lang (2004).

Trunk cross-sectional area (TCSA) at $20 \mathrm{~cm}$ above the graft union was calculated in late spring from measurements of trunk circumference.

Crop value per tree was calculated from fruit yield and size relationships determined in 2003. Values per size category used in the calculations are outlined in Table 1. Values are based upon average returns for fresh market quality 'Bing' sweet cherries from 2002 and 2003 (G. Allan, Allan Bros. Packing, personal communication) and include packaging and marketing fees.

The experiment was organized in a factorial treatment arrangement in a randomized complete block design with 3 blocks. The two factors evaluated were rootstock (3) and training system (4). Analyses of variance were conducted using the General Linear Models (GLM) procedure in the Statistical Analysis System (SAS) program package (SAS Institute, Cary, N.C.) and means were compared by Fisher's least significant difference (LSD) at 0.05 .

\section{Results and Discussion}

Vigor effects. Rootstock genotype affected tree vigor (Fig. 1). Across training systems, Mazzard was the most vigorous rootstock and 'Gisela 5' was the most vigor-controlling rootstock, reducing TCSA to $54 \%$ of Mazzard-rooted trees in 2003. 'Gisela 6' was intermediate in its vigor control, reducing TCSA to $80 \%$ of Mazzard-rooted trees by 2003 . However, because tree density was similar for all rootstocks, the vigor response we observed may underestimate the actual size controlling potential of 'Gisela 5', which, in a commercial operation would be planted at higher densities. Other factors being equal, sweet cherry tree vigor is inversely proportional to tree density (Meland, 1998). Very little research has examined the mechanism(s) of dwarfing in sweet cherry; in other tree fruit species, dwarfing rootstocks have been reported to affect water relations (Basile et al., 2003), hydraulic resistance (Atkinson et al., 2003) and hormonal signals (Kamboj et al., 1999). In sweet cherry, 'Gisela 5'-rooted trees exhibited vascular anomalies within the graft union (e.g, whorls of xylem tissue, reduced vessel size), and differences in the seasonal pattern of carbohydrate accumulation and reallocation surrounding the graft union, compared to standard Mazzard (Olmstead, 2004).

The size-controlling properties of Gisela rootstocks were not apparent until several years after planting. Not until 1998, in the trees' fourth year in the orchard, did significant differences in TCSA exist (Fig. 1) when 'Gisela

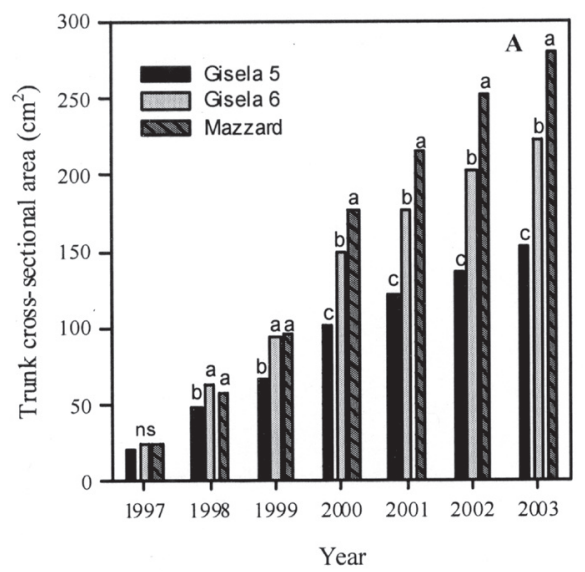

5 ' trees had about $20 \%$ less TCSA than trees on 'Gisela 6' and Mazzard rootstocks. 'Gisela 6' and Mazzard-rooted trees exhibited similar vigor until 2000, when trees on 'Gisela 6' were about $20 \%$ less vigorous. Differences among rootstocks became more pronounced with age and as fruit yield increased. Whiting and Lang (2004) showed that trunk radial expansion of 'Bing'/'Gisela 5' trees is related negatively to canopy fruit-to-leaf area ratios. The current data suggest that a similar relationship exists irrespective of rootstock genotype. Fitted linear trends for TCSA over time were highly significant $\left(r^{2}=0.98\right)$. The slope of the fitted response for Mazzard was 26\% and 51\% higher compared with 'Gisela 6' and 'Gisela 5', respectively.

Differences in tree vigor among training systems were less pronounced than those among rootstocks (Fig. 1B) and there was no significant interaction between training system and rootstock. Only subtle (i.e., $<10 \%$ ) differences were evident in the first 4 years following planting though B-trained trees were significantly smaller through 1998. This is likely due to the increased pruning, especially summer pruning, during the first two years of growth. By 1999, no training system differed from the others, but significant differences became evident in 2000 as CL and $P$ trained trees began exhibiting less vigor than the $\mathrm{B}$ and $\mathrm{Y}$ trees

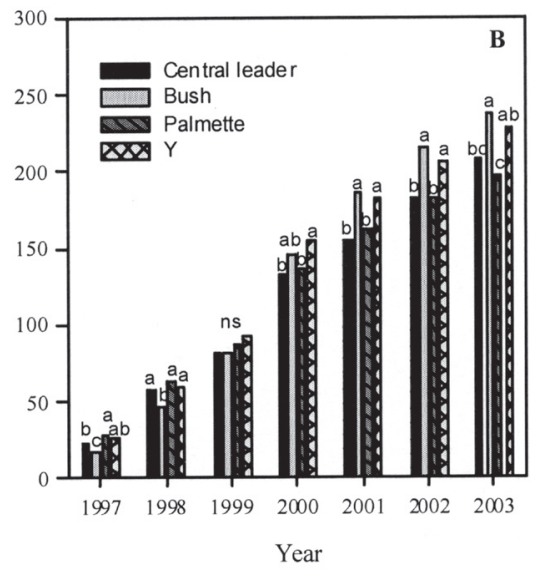

Fig. 1. Trunk cross-sectional areas $\left(\mathrm{cm}^{2}\right)$ of 'Bing' sweet cherries as influenced by rootstock (A) or training system (B). Statistical comparisons are within year at $P>0.05$.
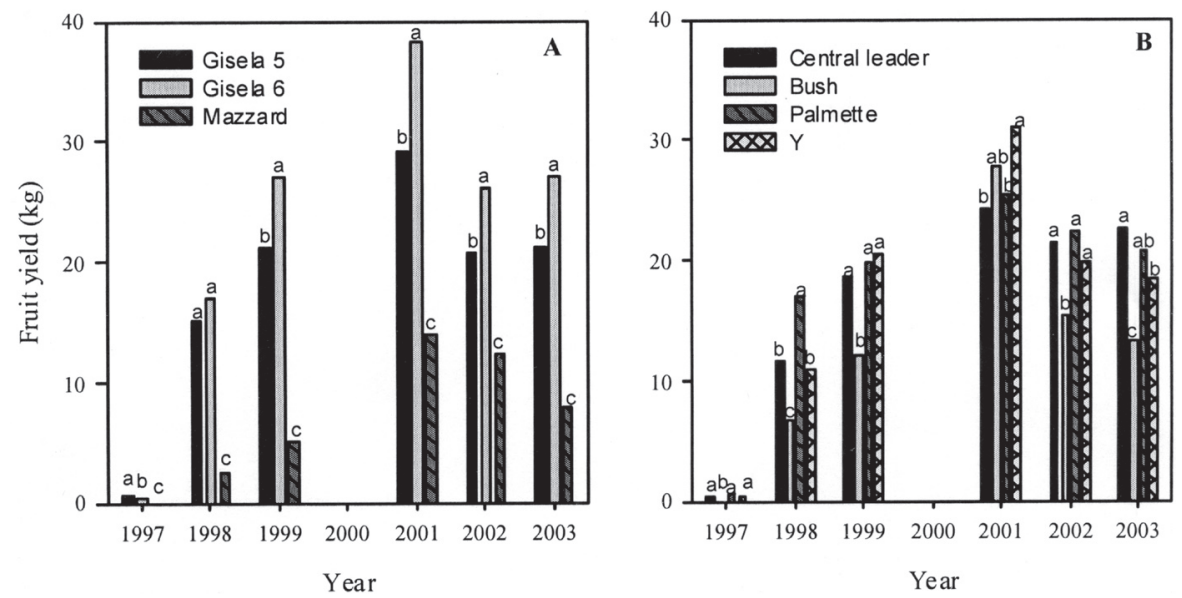

Fig. 2. Yield (kg/tree) of 'Bing' sweet cherries as influenced by rootstock (A) or training system (B). Statistical comparisons are within year at $P>0.05$. 
Table 2. Weight and percent premium 'Bing' sweet cherry fruit harvested from trees grown on three rootstocks with four training systems. Data are 7-year means. Means within a column followed by the same letter are not statistically different $(P<0.05)$.

\begin{tabular}{|c|c|c|c|}
\hline Rootstock & $\begin{array}{l}\text { Training } \\
\text { system }\end{array}$ & $\begin{array}{c}\text { Fruit } \\
\text { wt } \\
(\mathrm{g})\end{array}$ & $\begin{array}{c}\text { 10-Rows } \\
\text { and larger } \\
(\%)\end{array}$ \\
\hline \multirow[t]{4}{*}{ 'Gisela 5' } & Central leader & $6.5 \mathrm{de}$ & $3.1 \mathrm{e}$ \\
\hline & Bush & $7.2 \mathrm{bc}$ & $14.2 \mathrm{~cd}$ \\
\hline & Palmette & $6.0 \mathrm{f}$ & $3.0 \mathrm{e}$ \\
\hline & Y-trellis & $6.5 \mathrm{de}$ & $5.4 \mathrm{de}$ \\
\hline \multirow[t]{4}{*}{ 'Gisela 6' } & Central leader & $6.3 \mathrm{def}$ & $5.2 \mathrm{de}$ \\
\hline & Bush & $7.4 \mathrm{~b}$ & $21.3 \mathrm{bc}$ \\
\hline & Palmette & $6.2 \mathrm{ef}$ & $3.5 \mathrm{e}$ \\
\hline & Y-trellis & $6.8 \mathrm{~cd}$ & $10.6 \mathrm{de}$ \\
\hline \multirow[t]{4}{*}{ Mazzard } & Central leader & $7.6 \mathrm{~b}$ & $25.6 \mathrm{ab}$ \\
\hline & Bush & $7.7 \mathrm{ab}$ & $24.0 \mathrm{~b}$ \\
\hline & Palmette & $7.8 \mathrm{ab}$ & $25.9 \mathrm{ab}$ \\
\hline & Y-trellis & $8.2 \mathrm{a}$ & $33.4 \mathrm{a}$ \\
\hline
\end{tabular}

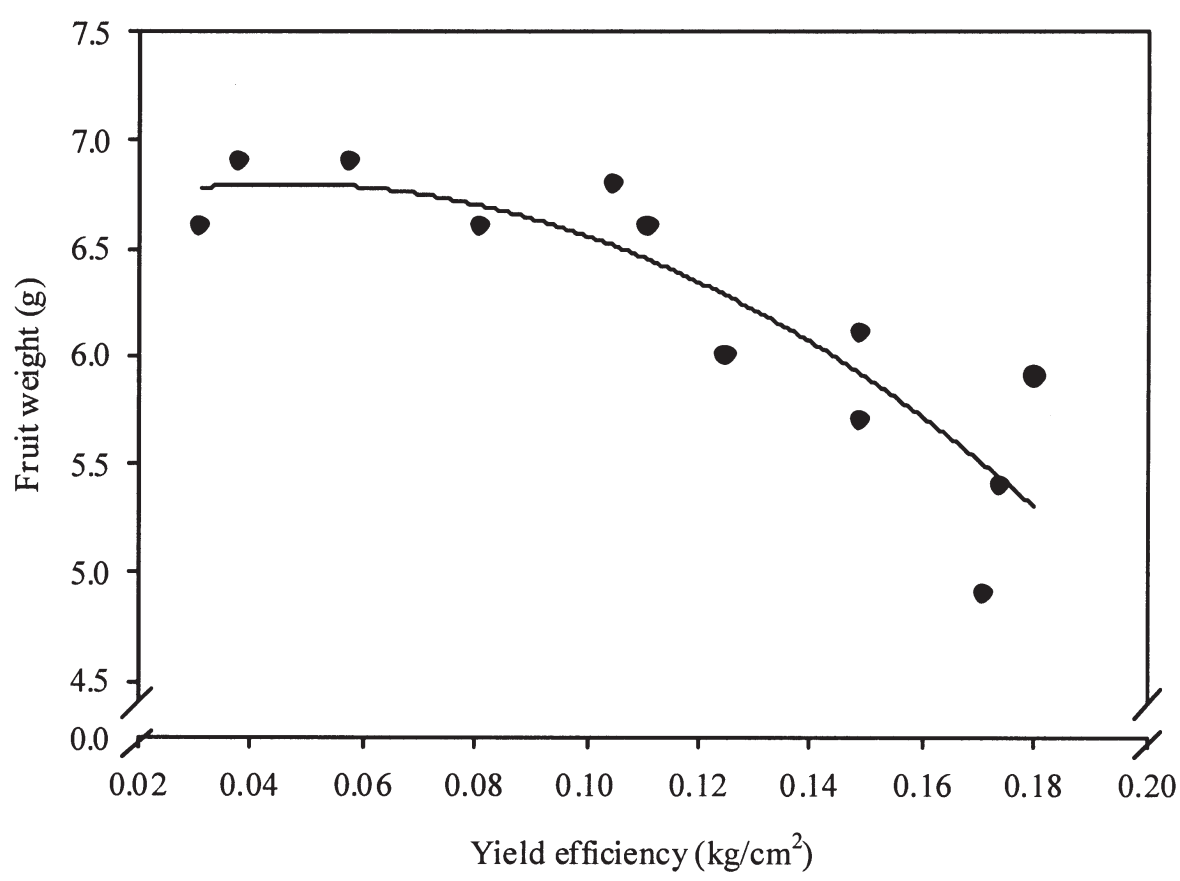

Fig. 3. Relationship between 9-year-old of 'Bing' sweet cherry tree yield efficiency $\left[\mathrm{kg}\right.$ fruit $/ \mathrm{cm}^{2}$ trunk cross-sectional area (TCSA)] and individual fruit weight. Trees were grown on three rootstocks and four training systems; $\mathrm{y}=6.3+7.7 \mathrm{x}-83.3 \mathrm{x}^{2}, r^{2}=0.77, p>0.001, \mathrm{n}=12$.

which continued through 2003. However, by 2002, CL and $P$ trees were only about $15 \%$ less vigorous than $\mathrm{B}$ and $\mathrm{Y}$. Early training of $\mathrm{Y}$, and especially $\mathrm{B}$, involved more branch heading cuts which may have increased the number of vegetative meristems and ultimately promoted greater trunk expansion in these systems. In addition, B trees were initially lower yielding compared to other systems, and radial trunk expansion is reduced by high crop load (Whiting and Lang, 2004). Analysis of the slope of fitted linear regressions for TCSA over time $\left(r^{2}=0.99\right)$ further highlights the differences in vigor among training systems: $\mathrm{B}$ was the most vigorous, and $\mathrm{Y}, \mathrm{CL}$, and $\mathrm{P}$ exhibited slopes $10 \%, 20 \%$, and $25 \%$ lower, respectively. However, the experimental orchard was planted at uniform density. Traditionally, Y and CL systems are planted at higher densities than multiple leader systems like B and P.

Yield effects. Rootstock had a tremendous effect on tree precocity and productivity (Fig. 2A). Overall, 'Gisela 6'-rooted trees were the most productive, yielding between $13 \%$ and
$31 \%$ more than 'Gisela 5'-rooted trees and $657 \%$ to $212 \%$ more than Mazzard-rooted trees, depending on the year. Both 'Gisela 5' and 'Gisela 6' were significantly more precocious than Mazzard and induced fruiting two years after planting. Fruit yield in 1998 and 1999 from Gisela-rooted trees was about 4.5- to 6.5-fold higher compared to Mazzardrooted trees. Cumulative yields of 'Gisela 6', 'Gisela 5', and Mazzard rootstocks were 136, 108 , and $42 \mathrm{~kg}$, respectively. The precocity of the Gisela series rootstocks is of particular interest to sweet cherry growers because the revenue from early fruit sales allows growers to recoup the costs of orchard establishment sooner (Seavert et al., 2002). Preliminary estimates indicate that the precocity of 'Gisela 5 ' and 'Gisela 6' rootstocks, allows growers to break even financially 7 years before they would with Mazzard-rooted trees (Seavert et al., 2002) despite the higher cost of Giselarooted nurserystock.

Training system had a slight and somewhat inconsistent effect on tree precocity and productivity (Fig. 2B). Most notably, B trees exhibited lower yields compared to the other architectures, which were similar. Cumulative yields from $\mathrm{P}, \mathrm{Y}$, and CL trees were about 102 $\mathrm{kg}$. B trees were about $25 \%$ less productive, yielding $75 \mathrm{~kg}$ over the 6 years. Lower precocity from B trees likely is a result of repeated summer and dormant pruning during the first 3 years after planting. Such pruning cuts limit vegetative extension growth and, thereby, future fruiting sites. These relationships have not been reported previously for sweet cherry in the PNW. However, previous research on 'Van' sweet cherry found a Y-trellis system to be the most productive (Meland, 1998) compared to vertical axis, free spindle, and multiple leader vase architectures.

Tree density has an enormous effect on fruit yield and, to a lesser extent, tree growth. Generally, yield is positively, and growth is negatively, related to tree density (Meland, 1998; Robinson, 1997), up to a point. This is particularly true at low tree densities but yield increases at a decreasing rate as tree density increases. The tree spacing of this trial $(2.6 \times$ $4.9 \mathrm{~m}$ ) is considered high density in the PNW, particularly for Mazzard-rooted trees. Indeed, the inherent vigor of Mazzard rootstock and the orchard site made the trees difficult to maintain within this spacing. Planting Mazzard-rooted trees at a lower density may improve light distribution throughout the canopy and, thereby, improve floral bud induction and, potentially, yield from the lower, heavily shaded portions of the canopy. In contrast, tree spacing in this trial was appropriate for 'Gisela 6', and suboptimal for 'Gisela 5' rooted trees. Currently in the PNW, growers are planting 'Gisela 5 '-rooted orchards at 1.75 to $2.5 \mathrm{~m}$ within the row and 4.5 to $5 \mathrm{~m}$ between rows (i.e., 890 to 1420 trees/ha). Tree density was not varied in this trial, but we expect orchard yield would increase proportional to the change from 840 trees/ha because yield per unit land area is positively related to tree density (Meland, 1998). This would favor the Gisela series rootstocks whose yield per tree was significantly greater than Mazzard (Fig. 2A). Research into the interactions among sweet cherry tree density, rootstock, yield and fruit quality is needed.

Fruit quality effects. Rootstock and training system affected fruit quality. In addition, there existed significant interaction between rootstock and training system (Table 2). For both 'Gisela 5' and 'Gisela 6', B architecture yielded the largest fruit and the P system yielded the smallest. Compared to the other systems, individual fruit weight from $B$ trees was about $15 \%$ heavier. This is due in large part, to the lower yield and higher vigor of B trees. In contrast, there were only slight $(<8 \%)$ differences in fruit weight among training systems for Mazzard-rooted trees. Across all years, the Y system yielded the largest fruit and CL the smallest. Across training systems, fruit weight was highest on Mazzard, and about 16\% lower on both 'Gisela' rootstocks. This highlights the most significant horticultural challenge to profitable adoption of precocious, productive, and dwarfing rootstocks for sweet cherry. There exists a clear negative relationship between 
Table 3. Fruit yield and gross crop value from 9-year-old 'Bing' sweet cherry trees grown on three rootstocks and four training systems.

\begin{tabular}{|c|c|c|c|c|}
\hline Rootstock & $\begin{array}{l}\text { Training } \\
\text { system }\end{array}$ & $\begin{array}{c}\text { Yield } \\
(\mathrm{kg})\end{array}$ & $\begin{array}{c}\text { Gross } \\
\text { crop } \\
\text { value } \\
(\$ / \text { tree) }\end{array}$ & $\begin{array}{c}\text { Gross } \\
\text { crop } \\
\text { value } \\
(\$ / \mathrm{kg}) \\
\end{array}$ \\
\hline \multirow[t]{4}{*}{ 'Gisela 5' } & Central leader & 25.7 & 44.1 & 1.72 \\
\hline & Bush & 16.1 & 32.7 & 2.03 \\
\hline & Palmette & 20.1 & 27.2 & 1.35 \\
\hline & Y-trellis & 23.3 & 39.8 & 1.71 \\
\hline \multirow[t]{4}{*}{ 'Gisela 6' } & Central leader & 29.9 & 68.9 & 2.30 \\
\hline & Bush & 19.0 & 47.9 & 2.52 \\
\hline & Palmette & 31.4 & 58.3 & 1.86 \\
\hline & Y-trellis & 27.7 & 63.8 & 2.30 \\
\hline \multirow[t]{4}{*}{ Mazzard } & Central leader & 12.5 & 37.6 & 3.01 \\
\hline & Bush & 4.5 & 12.3 & 2.73 \\
\hline & Palmette & 10.7 & 34.1 & 3.19 \\
\hline & Y-trellis & 4.3 & 13.6 & 3.16 \\
\hline
\end{tabular}

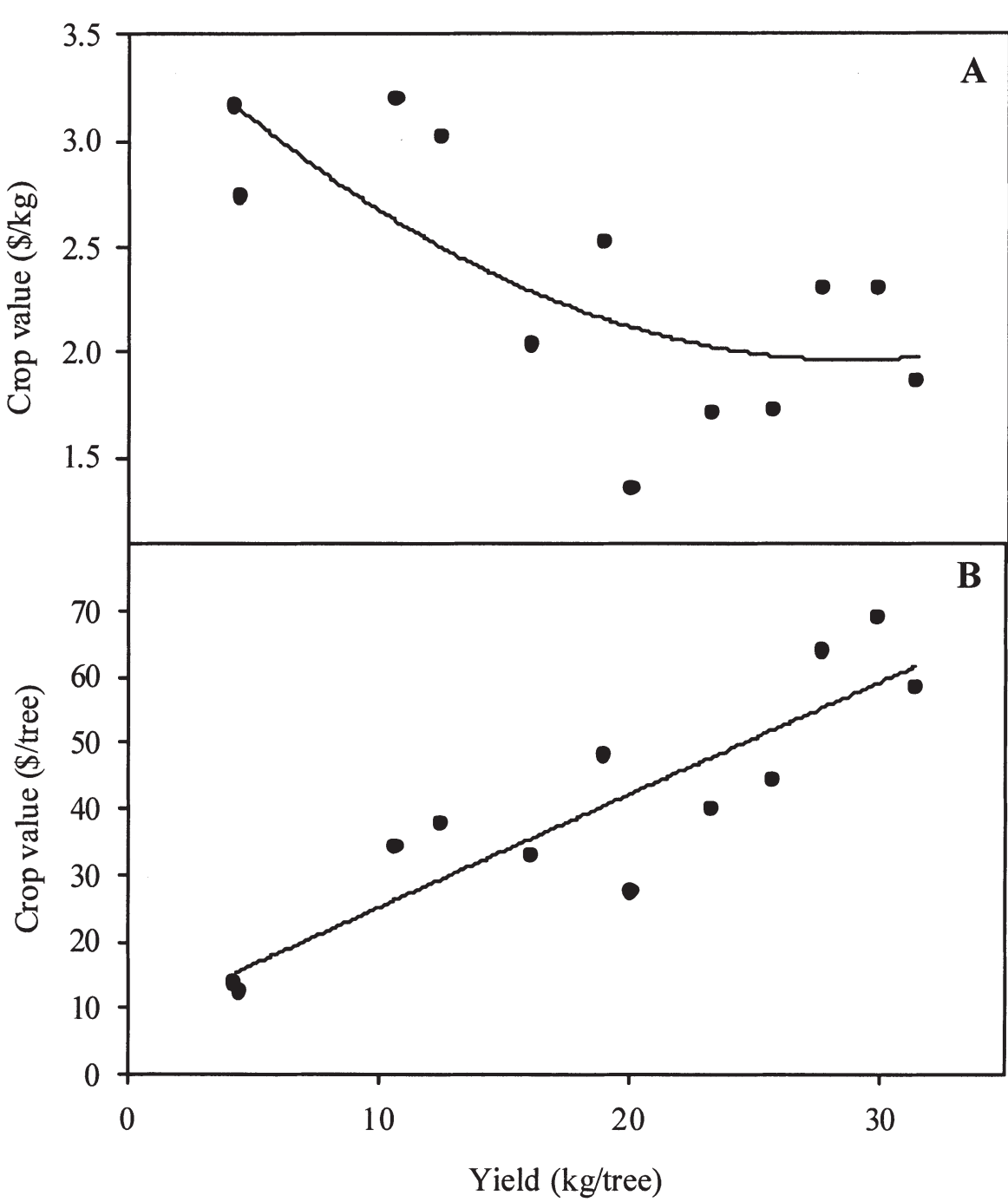

Fig. 4. Relationship between 9-year-old of 'Bing' sweet cherry trees grown on three rootstocks and four training systems and gross crop value (A) per kg of fruit and (B) per tree. (A) $y=3.6-0.12 x+0.002 x^{2}$, $r^{2}=0.53, p<0.03$. (B) $\mathrm{y}=7.96+1.17 \mathrm{x}, r^{2}=0.79, p<0.0001, \mathrm{n}=12$

sweet cherry canopy fruit-to-leaf area ratio (F:LA) and fruit quality (Whiting and Lang, 2004). Each tree was pruned only for light penetration and to maintain tree spacing. Modified pruning strategies that limit future fruiting sites and balance crop load with vegetative vigor (i.e., photosynthetic capacity) must be utilized for Gisela-rooted trees. This is most readily accomplished by heading new shoot from Mazzard-rooted trees (M.D. Whiting, unpublished).

Sweet cherry fruit usually are marketed by diameter or row size (an industry sales designation); larger fruit are more valuable than smaller fruit (Table 1). Fruit that are about $26.6 \mathrm{~mm}$ (10-row) or larger are considered premium quality. Analysis of fruit row size affirms the benefits of B architecture for 'Gisela'-rooted trees. Compared with the other systems, among which there were no differences, B-trained trees yielded about a 3.5-fold higher percentage of fruit in the premium size category (Table 2). This again largely reflects favorable canopy fruit-to-leaf area ratios from B trees and less competition for photoassimilates among developing fruit, although canopy leaf area was not measured in this trial. Mazzard-rooted trees bore a higher proportion of $26.6 \mathrm{~mm}$ and larger fruit compared to both 'Gisela' rootstocks, but yielded less in this premium size category due to lower tree yield. Similar to fruit weight, training system had only a slight effect on fruit size. On Mazzard rootstock, $\mathrm{Y}$ yielded the highest percent premium fruit and $\mathrm{B}$ yielded the lowest. The promotion of vegetative vigor by pruning-intensive training strategies like the B system can result in low yields on vigorous rootstocks due to excessive vegetative growth, while they can promote a more balanced canopy on dwarfing precocious rootstocks that otherwise would be unbalanced in favor of reproductive growth. To our knowledge, these interactions have not been reported previously for sweet cherry.

For mature trees and across rootstocks, the relationship between fruit weight and whole tree yield efficiency in 2002 was negative and curvilinear (Fig. 3). This relationship was similar in 2003 as well (data not shown). This reflects increased competition for photoassimilates within trees exhibiting high yield efficiency (i.e., bearing large crops within a limited size canopy). This response supports earlier work that documented a close negative relation between fruit quality and fruit-to-leaf area ratio (Roper and Loescher, 1987; Whiting and Lang, 2004). This also underscores the importance of balancing crop load with canopy area to achieve good fruit quality, especially on new rootstocks that not only limit vigor, but also promote earlier and more extensive flower bud formation (Maguylo et al., 2004). A threshold exists around $0.1 \mathrm{~kg} \cdot \mathrm{cm}^{-2}$ TCSA, above which fruit size declines more rapidly with increasing yield efficiency. Interestingly, this threshold is close to that discovered within 'Bing' and 'Gisela 5' trees thinned to varying fruit-to-leaf area ratios (Whiting and Lang, 2004). This suggests that, to achieve optimum fruit size under our conditions, 'Gisela 5' rooted trees should bear a maximum of about $14 \mathrm{~kg}$ fruit/tree. In practice, this represents a reduction of about $33 \%$ to $50 \%$ of the natural yield for mature 'Bing'/ 'Gisela 5' trees (20 to $30 \mathrm{~kg}$; Fig. 2, Whiting and Lang, 2004). This converts to about $12.1 \mathrm{mt}$ per ha at 864 trees/ha-about $15 \%$ to $20 \%$ higher than the average yield of sweet cherry orchards in Washington State. However, greater tree densities can be achieved on 'Gisela 5', and 
yield per ha would increase proportionally, up to a point. Similarly, optimum crop load of 'Gisela 6'-rooted trees is about $20 \mathrm{~kg} /$ tree, again requiring about a $33 \%$ to $50 \%$ reduction in natural crop load for maximum fruit quality. At 864 trees/ha, this translates into $17.3 \mathrm{t} \cdot \mathrm{ha}^{-1}$. In contrast, Mazzard-rooted trees would be optimized at about $25 \mathrm{~kg} /$ tree because of the greater canopy volume to support fruit growth. Actual yields of 8-year-old Mazzard-rooted trees were about half of the estimated optimum (Fig. 2). The lack of productivity on Mazzard rootstock due to lower flower bud formation remains a significant challenge. However, caution must be taken when interpreting these results, because the effects of rootstock on dry matter partitioning are unknown. Regardless, this analysis underscores the need for distinctly different crop load management strategies for sweet cherry orchard systems based on Gisela or Mazzard rootstocks.

Preliminaryeconomic analyses. Profitability of any orchard system depends upon fruit yield, quality, price, and the expenses involved in planting, maintaining and harvesting the orchard (Seavert et al., 2002). For a preliminary analysis of the economic relationships between rootstocks and training systems, we compared only crop value per tree based on detailed yield and size data collected in 2003 (Table 3 ). This analysis assumes a $100 \%$ packout and no cullage difference among training systems and rootstocks (i.e., similar quantity of fruit surface blemishes or other damage). On a single tree basis, we calculated the greatest crop value for 'Gisela 6'-rooted trees, irrespective of training system. Compared to 'Gisela 6', across training systems, returns were $40 \%$ and $60 \%$ less for 'Gisela 5' and Mazzard rootstocks, respectively. This is due to the high yields from 'Gisela 6', despite better fruit quality from Mazzard-rooted trees. Indeed, tree yield is related linearly and closely to gross returns per tree (Fig. 4B). Irrespective of rootstock, the highest yielding system provided the best crop value per tree. The current analyses suggest that growers are rewarded for producing high yields of lower quality fruit compared to low yields of top-quality fruit. However, we expect the response to eventually become hyperbolic or even parabolic as fruit quality declines with increasing yields or as higher premiums are paid for larger fruit. Increased sweet cherry production in the PNW has already elicited a shift in the price structure in favor of larger, higher quality fruit. Additionally, the high cost of hand-picking becomes proportionally higher for large volumes of small fruit compared to lower volumes of large fruit.

Comparing gross crop value $(\$ / \mathrm{kg})$ is a means of evaluating treatment effects on fruit quality and yield relationships. The relationship between yield and crop value is negative and curvilinear (Fig. 4A). This is due to the negative relationship between fruit quality and yield (Whiting and Lang, 2004) and reflects lower prices paid for small fruit. Mazzard-rooted trees exhibited the best returns per $\mathrm{kg}$ fruit harvested due to high fruit quality (Table 3 ). For both Gisela rootstocks, B-trained trees exhibited the best returns per kg fruit, again because of higher fruit quality compared to other training systems. In addition, for both Gisela rootstocks, gross crop value of P-trained trees was about $24 \%$ lower than the other systems.

As discussed above, 864 trees/ha is an appropriate density for 'Gisela 6' but is low for 'Gisela 5'. We hypothesize that at higher densities, crop value per ha from 'Gisela 5' should approach that for 'Gisela 6'. This would occur, at about 1430 trees/ha, ceteris paribus. We have recently planted new experimental orchards at Washington State University on 'Gisela 5' at $1.75 \times 4.25 \mathrm{~m}$ (1345 trees/ha), to evaluate sweet cherry yield and quality potential under high density management. In addition, on 'Gisela 5' we expect lower costs of production, particularly pruning and harvest, due to smaller tree stature in comparison to 'Gisela 6' and especially Mazzard. Further research into the effects of tree density, yield, fruit quality, and production economics would be helpful for developing high density sweet cherry orchard system recommendations.

\section{Literature Cited}

Atkinson, C.J., M.A. Else, and L. Taylor. 2003. Root and stem hydraulic conductivity as determinants of growth potential in grafted trees of apple (Malus pumila Mill.). J. Expt. Bot. 54:1221-1229.

Autio, W.R. and F.W. Southwick. 1986. The effects of rootstock and root-interstem combination on the growth, productivity, and anchorage of a spur and standard strain Delicious apple tree. Fruit Var. J. 40:128-133.

Basile, B., J. Marsal, and T.M. DeJong. 2003. Daily shoot extension growth of peach trees growing on rootstocks that reduce scion growth is related to daily dynamics of stem water potential. Tree Physiol. 23:695-704.

Fallahi, E., W.M. Colt, B. Fallahi, and I.J. Chun. 2002. The importance of apple rootstocks on tree growth, yield, fruit quality, leaf nutrition, and photosynthesis with an emphasis on 'Fuji'. HortTechnology 12:38-44.

Ferree, D.C., K.A. Clayton-Greene, and B. Bishop. 1993. Influence of orchard management system on canopy composition, light distribution, net photosynthesis and transpiration of apple trees. J. Hort. Sci. 68:377-392.

Hampson, C.R., H.A. Quamme, and R.T. Brownlee. 2002. Canopy growth, yield, and fruit quality of 'Royal Gala' apple trees grown for eight years in five tree training systems. HortScience $37: 627-631$

Jackson, J.E. 1980. Light interception and utilization by orchard systems. Hort. Rev. 2:208-267.

Kamboj, J.S., G. Browning, P.S. Blake, J.D. Quinlan, and D.A. Baker. 1999. GC-MS-SIM analysis of abscisic acid and indole-3-acetic acid in shoot bark of apple rootstocks. Plant Growth Reg. 28:21-27.

Kappel, F. and M. Bouthillier. 1995. Rootstock, severity of dormant pruning, and summer pruning influences on peach tree size, yield, and fruit quality. Can. J. Plant Sci. 75:491-496.

Lang, G.A. 2000. Precocious, dwarfing, and productive-How will new cherry rootstocks impact the sweet cherry industry? HortTechnology 10:719-725.

Layne, D.E.C. 1994. Prunus rootstocks affect long-term orchard performance of 'Redhaven' peach on Brookston clay loam. HortScience 29:167-171.

Long, L. 2001. Cherry training systems: selection and development. Ore. State Univ. Pacific NW Ext. Publ. 543.

Maguylo, K., G.A. Lang, and R.L. Perry. 2004. Rootstock genotype affects flower distribution and density of 'Hedelfinger' sweet cherry and 'Montmorency' sour cherry. Acta Hort. 636:259-266.

Marini, R.P., J.A. Barden, J.A. Cline, R.L. Perry, and T. Robinson. 2002. Effect of apple rootstocks on average 'Gala' fruit weight at four locations after adjusting for crop load. J. Amer. Sci. Hort. Sci. 127:749-753.

Meland, M. 1998. Yield and fruit quality of 'Van' sweet cherry in four high density production systems over seven years. Acta Hort. 468:425-432.

Miller, S.S. 1984. Effect of various training systems on canopy development in four apple cultivars. Acta Hort. 146:293-303.

Moreno, J., F. Toribio, and M.A. Manzano. 1998. Evaluation of palmette, marchand and vase training systems in cherry varieties. Acta Hort. 468:485-489.

Olmstead, M. 2004. Vascular and metabolic impact of dwarfing rootstocks on sweet cherry (Prunus avium, L.). $\mathrm{PhD}$ diss. Mich. State Univ., East Lansing.

Perry R., G. Lang, R. Andersen, L.Anderson, A. Azarenko, T. Facteau, D. Ferree, A. Gaus, F. Kappel, F. Morrison, C. Rom, T. Roper, S. Southwick, G. Tehrani, and C. Walsh. 1997. Performance of the NC-140 cherry rootstock trials in North America. Acta Hort. 451:225-229.

Robinson, T.L. 1997. Interaction of tree form and rootstock on light interception, yield and efficiency of 'Empire', 'Delicious', and 'Jonagold' apple trees trained to different systems. Acta Hort. 451:327-436.

Robinson, T.L., A.N. Lakso, and S.G. Carpenter. 1991. Canopy development, yield, and fruit quality of 'Empire' and 'Delicious' apple trees grown in four orchard production systems for ten years. J. Amer. Soc. Hort. Sci. 116:179-187.

Roose, M.L., D.A. Cole, D. Atkin, and R.S. Kupper. 1989. Yield and tree size of four citrus cultivars on 21 rootstocks in California. J. Amer. Soc. Hort. Sci. 114:678-684.

Roper, T.R. and W.H. Loescher. 1987. Relationships between leaf area per fruit and fruit quality in 'Bing' sweet cherry. HortScience 22:1273-1276.

Schecter, I., D.C. Elfving, and J.T.A. Proctor. 1991. Rootstock affects vegetative growth characteristics and productivity of 'Delicious' apple. HortScience 9:1145-1148.

Seavert, C.F., M.K. White, and L.E. Long. 2002. Orchard economics: establishing and producing standard- and high-density sweet cherries in Wasco county. Oregon State Univ. Ext. Bul. EM 8802.

Webster, A.D. and H. Schmidt. 1996. Rootstocks for sweet and sour cherries, p. 127-163. In A.D. Webster and N.E. Looney (eds.). Cherries: Crop physiology, production and uses. CAB Intl., Wallingford, Oxon, U.K.

Wheaton, T.A., W.S. Castle, J.D. Whitney, and D.P.H. Tucker. 1991. Performance of citrus scion cultivars and rootstocks in a high-density planting. HortScience 26:837-840.

Whiting, M.D. and G.A. Lang. 2004. 'Bing' sweet cherry on the dwarfing rootstock 'Gisela 5': Crop load affects fruit quality and vegetative growth but not net $\mathrm{CO}_{2}$ exchange. J. Amer. Soc. Hort. Sci. 129:407-415. 